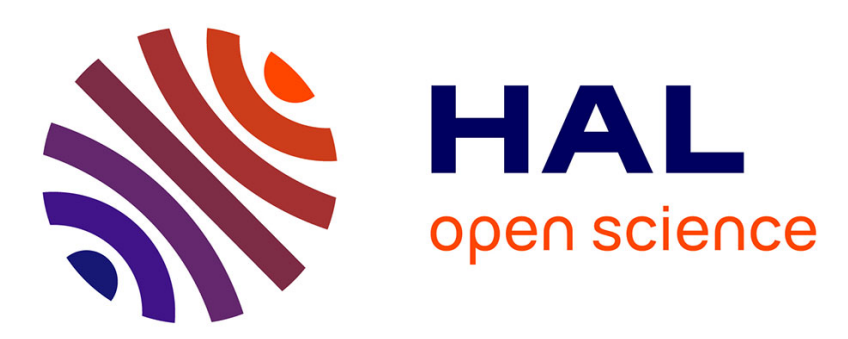

\title{
Aclidinium bromide provides long-acting bronchodilation in patients with COPD
}

Pascal Chanez, P.S. Burge, R. Dahl, J. Creemers, A. Chuchalin, R. Lamarca, E. Garcia Gil

\section{- To cite this version:}

Pascal Chanez, P.S. Burge, R. Dahl, J. Creemers, A. Chuchalin, et al.. Aclidinium bromide provides long-acting bronchodilation in patients with COPD. Pulmonary Pharmacology \& Therapeutics, 2010, 23 (1), pp.15. 10.1016/j.pupt.2009.08.001 . hal-00610665

\section{HAL Id: hal-00610665 https://hal.science/hal-00610665}

Submitted on 23 Jul 2011

HAL is a multi-disciplinary open access archive for the deposit and dissemination of scientific research documents, whether they are published or not. The documents may come from teaching and research institutions in France or abroad, or from public or private research centers.
L'archive ouverte pluridisciplinaire HAL, est destinée au dépôt et à la diffusion de documents scientifiques de niveau recherche, publiés ou non, émanant des établissements d'enseignement et de recherche français ou étrangers, des laboratoires publics ou privés. 


\section{Accepted Manuscript}

Title: Aclidinium bromide provides long-acting bronchodilation in patients with COPD

Authors: P. Chanez, P.S. Burge, R. Dahl, J. Creemers, A. Chuchalin, R. Lamarca, E. Garcia Gil

PII: S1094-5539(09)00096-0

DOI: $\quad$ 10.1016/j.pupt.2009.08.001

Reference: $\quad$ YPUPT 945

To appear in: Pulmonary Pharmacology \& Therapeutics

Received Date: 9 February 2009

Revised Date: 4 August 2009

Accepted Date: 10 August 2009

Please cite this article as: Chanez P, Burge PS, Dahl R, Creemers J, Chuchalin A, Lamarca R, Gil EG. Aclidinium bromide provides long-acting bronchodilation in patients with COPD, Pulmonary Pharmacology \& Therapeutics (2009), doi: 10.1016/j.pupt.2009.08.001

This is a PDF file of an unedited manuscript that has been accepted for publication. As a service to our customers we are providing this early version of the manuscript. The manuscript will undergo copyediting, typesetting, and review of the resulting proof before it is published in its final form. Please note that during the production process errors may be discovered which could affect the content, and all legal disclaimers that apply to the journal pertain. 


\section{Aclidinium bromide provides long-acting bronchodilation in patients with COPD}

P. Chanez, ${ }^{\mathrm{a}^{*}}$ P.S. Burge, ${ }^{\mathrm{b}}$ R. Dahl,${ }^{\mathrm{c}}$ J. Creemers, ${ }^{\mathrm{d}}$ A. Chuchalin, ${ }^{\mathrm{e}}$

R. Lamarca, ${ }^{f}$ E. Garcia Gil ${ }^{f}$

${ }^{a}$ Université de la Mediterranée AP-HM, 270 boulevard de Sainte-Marguerite, F-13009 Marseille, France

${ }^{b}$ Birmingham Heartlands Hospital, Birmingham, B9 5ST, UK

${ }^{c}$ Aarhus University Hospital, Noerrebrogade 44, DK-8000 Aarhus C, Denmark

${ }^{d}$ Catharina Hospital, Afdeling Longgeneeskunde, Postbus 1350, 5602 ZA Eindhoven, The Netherlands

${ }^{e}$ Russian State Medical University, Pulmonology Research Institute, 11-th Parkovaya str. 32/61, 105077 Moscow, Russia

${ }^{f}$ Almirall, R\&D Centre, Ronda General Mitre 151, 08022 Barcelona, Spain

\section{Corresponding author:}

Dr. Pascal Chanez

Département des Maladies Respiratoires,

AP-HM, Université de la Méditerranée,

270 boulevard de Sainte-Marguerite,

F-13009 Marseille, France

Tel: $+33(0) 491744630$

E-mail: Pascal.CHANEZ@univmed.fr

Keywords (6 words): Aclidinium, COPD, Bronchodilation, Phase II, FEV ${ }_{1}$, LAMA

Word count limited to 3000 words (excluding title page, abstract, references, tables and figures). Current count: 3493.

Footnote: Genuair ${ }^{\circledR}$ is a registered trademark of Almirall, Barcelona, Spain. 


\section{ABSTRACT}

Aclidinium bromide is a novel, long-acting, muscarinic antagonist in phase III development for the maintenance treatment of COPD. This phase IIb study investigated the efficacy and safety of aclidinium for the treatment of moderate to severe COPD to establish the optimal dose for phase III studies. A total of 464 patients with moderate to severe stable COPD were randomised to double-blind, once-daily treatment with aclidinium $(25,50,100,200$, or $400 \mu \mathrm{g})$, placebo, or openlabel tiotropium $(18 \mu \mathrm{g})$ for 4 weeks. Spirometric measurements were performed at 22-24 h after the first dose and then at weekly intervals, and from $0.5-6 \mathrm{~h}$ post-dose on day 1 and day 29. Compared with placebo, aclidinium $200 \mu \mathrm{g}$ and $400 \mu \mathrm{g}$ significantly increased trough $\mathrm{FEV}_{1}$ on day 29 versus baseline. During the first $6 \mathrm{~h}$ post-dose, the bronchodilatory effect of aclidinium (all doses) on day 1 was comparable to that on day 29. Time to peak $\mathrm{FEV}_{1}$ was $3 \mathrm{~h}$ for aclidinium 100$400 \mu \mathrm{g}$. Aclidinium was well tolerated, with no dose-dependent effect on ECG, laboratory parameters, or adverse events. The incidence of AEs was generally comparable to placebo. Aclidinium produced sustained bronchodilation over $24 \mathrm{~h}$ and was well tolerated during this short-term study. Based on these data, aclidinium 200 $\mu \mathrm{g}$ was selected as the investigational dose for future clinical trials in COPD. 


\section{Introduction}

Chronic obstructive pulmonary disease (COPD) is a preventable and treatable lung disease that is progressive and characterised by airflow limitation that is not fully reversible; it is associated with an abnormal inflammatory response of the lung to noxious particles or gases, particularly cigarette smoke [1]. COPD is highly prevalent [2], responsible for 2.7 million deaths globally in 2000 [3], and associated with increased morbidity and mortality as well as a reduced quality of life [4,5]. The 1997 Global Burden of Disease Study report has projected that COPD will become the third leading cause of death worldwide by 2020 [2].

Cholinergic mechanisms are involved in the pathophysiology of obstructive airways disease and, therefore, anticholinergic agents are considered to play a significant role in its treatment. There are currently only two approved anticholinergic treatment options for COPD; a short-acting agent, ipratropium, and a long-acting agent, tiotropium. The Global Initiative for Chronic Obstructive Lung Disease [1] recommends daily management of COPD with long-acting bronchodilators, such as anticholinergics, which offer more effective and convenient treatment than shortacting bronchodilators. Currently, there is only one approved long-acting anticholinergic bronchodilator, to which patients have different responses both in terms of efficacy and tolerability. Consequently, development of additional longacting anticholinergic treatment options is warranted.

Aclidinium bromide is a novel agent with specificity for muscarinic receptors currently in clinical development for the treatment of COPD. Preclinical studies have shown aclidinium to be a potent muscarinic receptor antagonist [6] that is rapidly hydrolysed in human plasma to two major inactive metabolites [6]. These pharmacologic properties give aclidinium a unique profile that could offer significant advantages to the COPD patient providing sustained bronchodilation and a reduced potential for systemic side effects.

The pharmacokinetics and pharmacodynamics of aclidinium have been investigated in phase I (doses of 50, 300, and $600 \mu \mathrm{g}$ ) [7] and phase IIa (doses of 100, 300, and $900 \mu \mathrm{g}$ ) [8] studies. The results from the phase I study showed that, in healthy 
subjects, aclidinium produced significant, long-lasting ( $\geq 24 \mathrm{~h})$ protection against methacholine-induced bronchoconstriction. The phase IIa study in patients with COPD showed that aclidinium provided sustained increases in forced expiratory volume in one second $\left(\mathrm{FEV}_{1}\right)$, which suggests suitability for once-daily dosing. In both studies, aclidinium was not detected in the plasma, which suggests a limited potential for systemic adverse events.

This phase IIb study was designed to assess the efficacy, safety, and tolerability of aclidinium compared with placebo, and to establish the optimal dose of aclidinium for use in phase III studies.

\section{Materials and methods}

\subsection{Centres}

This was a phase IIb study conducted in 42 centres in Europe and Russia. The trial was conducted in accordance with the amended Declaration of Helsinki (2002) and followed the International Conference on Harmonisation Good Clinical Practice Guidelines.

\subsection{Study subjects}

Male and female patients with a diagnosis of stable moderate to severe COPD according to American Thoracic Society criteria [9] were included in the study. Patients had to be $\geq 40$ years of age, have a smoking history of $\geq 10$ pack-years, and $\mathrm{FEV}_{1}$ in the range of $30-65 \%$ of predicted normal (Quanjer predicted normal value [10]) at the screening visit. At visit 1, the randomisation visit, pre-dose $\mathrm{FEV}_{1}$ had to be within $20 \%$ of the screening visit value. At both the screening visit and visit 1 , the ratio between $\mathrm{FEV}_{1}$ and forced vital capacity (FVC) was required to be $\leq 70 \%$.

Patients were excluded for any of the following reasons: history of or current asthma, allergic rhinitis, or atopy; reversibility to inhaled salbutamol $400 \mu \mathrm{g}>20 \%$ of predose value; blood eosinophil count $>400$ cells $/ \mathrm{mm}^{3}$; respiratory tract infection or COPD exacerbation within 1 month (or hospitalisation with 3 months) of the 
screening visit; clinically significant or relevant cardiovascular conditions, laboratory tests, or electrocardiogram (ECG) parameters; QTcB $>450 \mathrm{~ms}$; history of narrowangle glaucoma, symptomatic prostatic hypertrophy, or bladder neck obstruction.

Concomitant use of inhaled corticosteroids, oral sustained-release theophyllines (dosing suspended at least $48 \mathrm{~h}$ before each study visit), antihistamines, nedocromil, and ketotifen was permitted, provided a stable dose was administered prior to randomisation. The morning dose of these medications was delayed until after completion of the spirometry measurements at each visit. Salbutamol $100 \mu \mathrm{g} / \mathrm{puff}$ was allowed as rescue medication, although use was not permitted for $8 \mathrm{~h}$ prior to any visit. Any other medication used for the treatment of COPD was withdrawn prior to study start, and medications with pro-arrhythmic effects or that affected heart rate or QTc were not permitted.

\subsection{Study design}

This was a randomised, parallel-group, multicentre, double-blind (open-label for patients randomised to tiotropium), dose-finding study. After the screening visit, patients fulfilling the inclusion/exclusion criteria underwent a 14-day run-in period to ensure disease stability and washout of prohibited medications, followed by a 4-week treatment period during which they were randomised to one of seven treatments: aclidinium $25 \mu \mathrm{g}, 50 \mu \mathrm{g}, 100 \mu \mathrm{g}, 200 \mu \mathrm{g}$, or $400 \mu \mathrm{g}$; matching placebo; or tiotropium $18 \mu \mathrm{g}$. All treatments were taken once-daily in the morning between 08.00 and 12.00 . There were five study visits: day -14 (screening), days 1-2, day 8, day 15 , and day 29 .

Aclidinium and placebo were administered via a novel multi-dose dry-powder inhaler (Genuair $^{\circledR}$, Almirall Sofotec, Germany) developed from the Novolizer ${ }^{\circledR}$ which is approved and established in Europe. The new inhaler is a breath actuated, multidose, dry powder inhaler with a cyclone system for rapid particle dispersion, which generates a high fine particle dose (drug mass of particles $<5 \mu \mathrm{m}$ expressed as the percentage of the nominal dose that is available for deposition in the lungs) of 29$50 \%$ across a range of different drug types [10]. Tiotropium was administered via HandiHaler $^{\circledR}$. Aclidinium was supplied by Laboratorios Almirall, Spain, and tiotropium (Boehringer Ingelheim, Germany) was purchased commercially. 


\subsection{Measurements}

Two spirometry measurements were taken at 1-hour intervals at the screening visit and before randomisation on day 1 , and the averaged values provided the screening and baseline spirometry measurements. Efficacy spirometry measurements were taken at $0.5,1,2,3,4,5$, and $6 \mathrm{~h}$ after the first and last dose (days 1 and 29, respectively) in addition to 22,23 , and $24 \mathrm{~h}$ after the first dose and at each study visit (i.e. after the $7^{\text {th }}, 14^{\text {th }}$, and $28^{\text {th }}$ day of drug administration). Three acceptable readings were taken for each measurement at each time point according to the ATS/ERS recommendations on spirometric assessments [11].

The primary efficacy end point was trough $\mathrm{FEV}_{1}$ on day 29 for aclidinium (all doses) versus placebo. Trough $\mathrm{FEV}_{1}$ was defined as the mean value of the three highest readings assessed at 22,23 , and $24 \mathrm{~h}$ following the trial drug administration. Secondary end points included trough $\mathrm{FEV}_{1}$ on days 2, 8, and 15; trough FVC (defined in the same way as $\mathrm{FEV}_{1}$ ) on days 2, 8, 15, and 29; change from baseline in trough and peak $\mathrm{FEV}_{1}$ and $\mathrm{FVC}$; change from baseline in total and component (symptoms, activity, and impact) scores of the St. George's Respiratory Questionnaire (SGRQ); improvement in Transition Dyspnoea Index (TDI); number of days with COPD symptoms; change from baseline in average morning and evening peak expiratory flow rate (PEFR); and use of rescue medication throughout the study. Data on COPD symptoms, PEFR, and rescue medication were as recorded in the patient's diary.

Exploratory sub-group analyses of trough $\mathrm{FEV}_{1}$ at day 29 were performed by gender, age ( $<65$ years, $\geq 65$ years), COPD severity ( $\mathrm{FEV}_{1} \geq 50 \%$ predicted, $\geq 35-49 \%$ predicted, $<35 \%$ predicted), smoking status, responder or non-responder after first dose (responder was defined as increase in $\mathrm{FEV}_{1} \geq 12 \%$ and $\geq 200 \mathrm{ml}$ at $0-6$ hours), and response to salbutamol (increase over pre-dose $<12 \%, \geq 12 \%$ ).

Adverse events were recorded throughout the study. Other safety investigations included a 12-lead ECG at screening, day 1 and day 29, and laboratory tests for haematology, biochemistry and urinalysis at screening and day 29. 


\subsection{Statistical analysis}

The planned sample size was 413 evaluable patients (59 per treatment group). This number of patients provided a power of $80 \%$ to detect a difference of $120 \mathrm{ml}$ in trough $\mathrm{FEV}_{1}$ on day 29 between one of the aclidinium doses and placebo with a type I error rate of 0.05 (two-sided significance level). To allow for a dropout rate of $10 \%$ postrandomisation, it was planned to randomise a total of 462 patients (66 patients per treatment group).

Efficacy data are reported for the intent-to-treat (ITT) population, defined as all randomised patients who received at least one dose of study medication and who had a baseline and at least one post-baseline efficacy assessment. The safety population was comprised of all randomised patients who received at least one dose of study medication.

$\mathrm{FEV}_{1}$ and FVC variables, PEFR, SGRQ total score, TDI and use of rescue medication were evaluated using an analysis of covariance (ANCOVA) with treatment, country, and treatment-by-country interaction as factors, and baseline value as covariate. The interaction term was omitted from the model if it was not statistically significant. The treatment effect was initially assessed in an overall test with treatment comparisons undertaken only if this first test was statistically significant. Pairwise comparisons were based on Fisher's protected Least Significance Difference method to control for multiple tests. Treatment effects were estimated by least square means (LS Means), their standard errors (SE), and 95\% confidence intervals (CI). Data were analysed using the $\mathrm{SAS}^{\circledR}$ System version 8.2. Number of days with COPD symptoms, time to peak values, sub-group populations, and safety parameters were analysed descriptively.

Missing spirometry data were handled as follows: for discontinuations because of lack of efficacy, the least favourable value prior to discontinuation was imputed; for other discontinuations, the last value carried forward approach was used. When only some values were missing from a test day, linear interpolation was used to estimate a value missing between two valid measurements. If values were missing for an entire visit or at the beginning or the end of an assessment period (i.e. $0.5,6,22$, or $24 \mathrm{~h}$ ), timematched values of the previous available visit were used. 


\section{Results}

\subsection{Subject demographics}

A total of 464 patients were randomised to treatment, and 441 patients completed the study (Fig. 1). The safety population comprised all 464 patients, and the ITT population consisted of 460 patients. Baseline characteristics of the ITT population by treatment group are shown in Table 1 . The demographic and baseline characteristics for the ITT population were comparable across treatment groups.

\subsection{Trough $F E V_{1}$ on day 29}

Aclidinium increased trough $\mathrm{FEV}_{1}$ values on day 29 in a dose-dependent manner (primary efficacy variable; Fig. 2). Aclidinium at doses of $200 \mu \mathrm{g}$ and $400 \mu \mathrm{g}$ and tiotropium were statistically significantly more effective than placebo in increasing trough $\mathrm{FEV}_{1}$ at day 29. Adjusted mean differences in trough $\mathrm{FEV}_{1}$ for aclidinium compared with placebo were $39 \mathrm{ml}(25 \mu \mathrm{g} ; P>0.05), 36 \mathrm{ml}(50 \mu \mathrm{g} ; P>0.05), 83 \mathrm{ml}$ (100 $\mu \mathrm{g} ; P>0.05), 148 \mathrm{ml}(200 \mu \mathrm{g} ; P=0.006)$, and $128 \mathrm{ml}(400 \mu \mathrm{g} ; P=0.018)$; and for tiotropium compared with placebo the adjusted mean difference in $\mathrm{FEV}_{1}$ was $161 \mathrm{ml}(18 \mu \mathrm{g} ; P=0.003)$.

\subsection{Trough $\mathrm{FEV}_{1}$ at other time points}

After the first dose on day 1, a statistically significant increase in trough $\mathrm{FEV}_{1}$ compared with placebo was observed for aclidinium $200 \mu \mathrm{g}(P=0.044)$ and tiotropium $18 \mu \mathrm{g}(P=0.005)$. Across the four study visits, improvements in trough $\mathrm{FEV}_{1}$ were sustained in the active treatment groups, although with some variability observed on days 8 and 15 in the aclidinium $200 \mu$ group (Fig. 3).

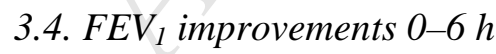

A dose-dependent increase in $\mathrm{FEV}_{1}$ was also observed following the first administration of aclidinium on day 1, with statistically significant increases from baseline in $\mathrm{FEV}_{1}$ versus placebo seen at the first assessment (30 min after dosing) and maintained through the first $6 \mathrm{~h}$ post-administration for the aclidinium $100 \mu \mathrm{g}$ 
$(P=0.014), 200 \mu \mathrm{g}(P<0.001)$, and $400 \mu \mathrm{g}(P<0.001)$ and tiotropium $18 \mu \mathrm{g}(P=0.02)$

(Fig. 4a). These changes were clinically significant at all time points for aclidinium $200 \mu \mathrm{g}$ and $400 \mu \mathrm{g}$ and tiotropium $18 \mu \mathrm{g}$.

On day 29, there were statistically significant increases in mean $\mathrm{FEV}_{1}$ over placebo throughout the 6-h assessment for aclidinium $100 \mu \mathrm{g}, 200 \mu \mathrm{g}$, and $400 \mu \mathrm{g}$, as well as for tiotropium $18 \mu \mathrm{g}(P<0.001$ in all cases except for the aclidinium $100 \mu \mathrm{g}$ dose: $P=0.006)$ (Fig. 4b).

\subsection{Changes in peak FEV $V_{1}$}

In line with the increases in mean $\mathrm{FEV}_{1}$, there were also dose-dependent increases in change from baseline in peak $\mathrm{FEV}_{1}$ for aclidinium 25-200 $\mu \mathrm{g}$ (Table 2). These changes were statistically significant and similar on day 1 and day 29 for aclidinium $100 \mu \mathrm{g}, 200 \mu \mathrm{g}$, and $400 \mu \mathrm{g}$ compared with placebo.

Median time to peak $\mathrm{FEV}_{1}$ on day 1 was $3 \mathrm{~h}$ for aclidinium $200 \mu \mathrm{g}$ and $400 \mu \mathrm{g}$ and $4 \mathrm{~h}$ for tiotropium $18 \mu \mathrm{g}$ (Table 2). On day 29, median time to peak $\mathrm{FEV}_{1}$ was $2 \mathrm{~h}$ for aclidinium $200 \mu \mathrm{g}$, and $3 \mathrm{~h}$ for aclidinium $400 \mu \mathrm{g}$ and tiotropium $18 \mu \mathrm{g}$ (Table 2).

\subsection{Changes in FVC}

Over the first $6 \mathrm{~h}$ following treatment on day 1, statistically significant improvements in FVC over baseline $(P \leq 0.028)$ were observed from 30 min post administration for aclidinium $200 \mu \mathrm{g}(0.1941)$ and $400 \mu \mathrm{g}(0.111$ 1), and tiotropium $18 \mu \mathrm{g}(0.108 \mathrm{l})$, and from $1 \mathrm{~h}$ post administration for aclidinium $50 \mu \mathrm{g}(0.120 \mathrm{l})$ and $100 \mu \mathrm{g}(0.150 \mathrm{l})$. Statistically significant improvements from baseline in FVC $(P \leq 0.024)$ were maintained throughout the $6 \mathrm{~h}$ post-dose period; at $6 \mathrm{~h}$ aclidinium $50 \mu \mathrm{g}(0.160 \mathrm{l})$, $200 \mu \mathrm{g}(0.224$ 1), and $400 \mu \mathrm{g}(0.140$ 1), and tiotropium $18 \mu \mathrm{g}(0.1861)$. On day 29, all treatments showed statistically significant increases over baseline in FVC $(P<0.035)$ at all time points assessed from $30 \mathrm{~min}-6 \mathrm{~h}$.

\subsection{Other secondary end points}

During the 4-week treatment period, the SGRQ total score decreased (improved) from baseline with all doses of aclidinium. The percentage of patients with a clinically 
meaningful improvement in SGRQ total score of $\geq 4$ points from baseline ranged from $52.6 \%$ in the $400 \mu \mathrm{g}$ group to $64.4 \%$ in the $100 \mu \mathrm{g}$ group. The improvements seen in the SGRQ were mainly due to changes in the symptoms and impacts components.

There was a trend towards an increase in TDI total score compared with placebo for all doses of aclidinium. Statistically significant increases in the TDI component scores functional impairment, magnitude of task, and transition focal component were seen with aclidinium $100 \mu \mathrm{g}$ and $400 \mu \mathrm{g}$ compared with placebo; there was no significant difference compared with placebo for any treatment group in the magnitude of effort component score.

Overall, there were no differences between any active treatment group and placebo in the mean number of days when COPD symptoms of breathlessness, cough, wheeze, or sputum were reported or the number of daily puffs of salbutamol taken as rescue medication compared with baseline.

\subsection{Safety evaluation}

Aclidinium was well tolerated; most AEs were mild to moderate in intensity and considered by the investigators to be unrelated to treatment. AEs reported by $\geq 2$ patients are shown in Table 3. The incidence of specific AEs was low across all active treatment groups and comparable with placebo, with the exception of headache, which occurred with an incidence of $>5 \%$ in the aclidinium $50 \mu \mathrm{g}$ and $100 \mu \mathrm{g}$ groups (6.2\% and $10.0 \%$, respectively), and dry mouth, which occurred with an incidence of $6.2 \%$ in the tiotropium group. There was no relationship between the dose of aclidinium and the number of AEs.

There was one non-fatal serious AE of severe COPD exacerbation after 1 day of treatment with aclidinium $100 \mu \mathrm{g}$ that resulted in the patient discontinuing the study. This AE was considered by the investigator as unlikely to be related to study drug. Six other patients withdrew from the study because of AEs: one in the placebo group, two in each of the aclidinium $50 \mu \mathrm{g}$ and $200 \mu \mathrm{g}$ groups, and one in the tiotropium $18 \mu \mathrm{g}$ group. The only AEs leading to withdrawal of more than one patient were cough, hoarseness, and dry mouth. 
There were no clinically relevant changes in laboratory parameters or vital signs in any of the treatment groups. The ECG results showed no dose-related changes in cardiovascular function associated with aclidinium treatment, and QTc changes from baseline were similar to placebo.

\section{Discussion}

The results from this randomised, parallel-group, dose-finding study showed that aclidinium provided a sustained $24-\mathrm{h}$ bronchodilation effect in patients with moderate to severe COPD that was significantly superior to placebo. The effect was maintained over the 4 weeks of the study, which indicated an absence of any treatment-associated tachyphylaxis. The aclidinium doses selected in this study ranged from an expected non-effective dose $(25 \mu \mathrm{g})$ to a known safe and effective dose $(400 \mu \mathrm{g})$. The trough $\mathrm{FEV}_{1}$ results showed a maximal effect with aclidinium $200 \mu \mathrm{g}$ daily. The minimum effective dose, defined as the lowest dose of aclidinium which significantly improved $\mathrm{FEV}_{1}$ over placebo on day 29, was $100 \mu \mathrm{g}$ in this COPD population.

Spirometric results observed for aclidinium $200 \mu \mathrm{g}$ and $400 \mu \mathrm{g}$ administered oncedaily were similar to those observed with tiotropium $18 \mu \mathrm{g}$ over the 4 weeks of the study. However, a direct comparison between aclidinium and tiotropium cannot be made as the tiotropium arm was included in the study for exploratory purposes and the drug was administered in an open-label fashion, which may have resulted in the introduction of bias to the tiotropium estimates. The mean increase in trough $\mathrm{FEV}_{1}$ for aclidinium $200 \mu \mathrm{g}$, aclidinium $400 \mu \mathrm{g}$ and tiotropium suggested clinically meaningful and significant bronchodilation $(\geq 200 \mathrm{ml})$ [12].

The variations in mean trough $\mathrm{FEV}_{1}$ seen at day 8 and day 15 with the aclidinium $200 \mu \mathrm{g}$ dose (Fig. 3) were unexpected observations. However, the differences between mean $\mathrm{FEV}_{1}$ on days 8 and 15 versus day 29 (the maximum value) were $\leq 65 \mathrm{ml}$. This variability is considered to be well within the acceptable $\mathrm{FEV}_{1}$ repeatability criteria of $150 \mathrm{ml}$, according to the latest ATS/ERS Task Force on Standardisation of Lung Function Testing [13]. As similar fluctuations in the trough $\mathrm{FEV}_{1}$ for aclidinium $200 \mu \mathrm{g}$ on days 8 and 15 were not observed with the aclidinium 
$100 \mu \mathrm{g}$ and $400 \mu \mathrm{g}$ doses, and consistent results were seen across all aclidinium doses for FVC, a parameter which is not likely to be affected by patient expiratory effort, it is considered that the $\mathrm{FEV}_{1}$ results for the $200 \mu \mathrm{g}$ dose are most likely due to random variability.

Although there was some evidence of a trend to a faster median time to peak $\mathrm{FEV}_{1}$ with aclidinium $200 \mu \mathrm{g}$ and $400 \mu \mathrm{g}$ compared with tiotropium, no conclusions can be drawn from these data due to the variability seen in each of the treatment groups. Additional studies will be required to determine whether these observations are substantiated.

During this study there was a trend towards improvements in the TDI total score and the SGRQ total score, although there was no apparent relationship with aclidinium dose. Whilst this was a short-term study, improvements in these variables over a longer time period could result in substantial improvements in patient quality of life and, therefore, these data are encouraging.

The type of AEs reported during the use of anticholinergic agents is important because muscarinic receptors are widely distributed outside of the airways and lungs. Therefore, it is important that such therapies have minimal systemic exposure to reduce the risk of unwanted systemic effects [14]. Previous studies have shown low and transient concentrations of aclidinium in plasma [8], suggesting that the incidence of systemic anticholinergic AEs would be very low [6]. The safety results from this study confirm a very low incidence of reported AEs with all doses of aclidinium.

Patients were not allowed in this study if they had a reversibility to inhaled salbutamol $400 \mu \mathrm{g} \geq 20 \%$ of pre-dose value in order to exclude highly reversible patients. Results from the recent studies indicate that patients with COPD demonstrate substantial acute bronchodilator reversibility using three different published criteria [15], suggesting that partial reversibility $\left(\mathrm{FEV}_{1}\right.$ change $\geq 12 \%$ after maximal bronchodilation) should no longer be an exclusion criterion in clinical trials. In our study, the mean reversibility to salbutamol of the study population at baseline was $7.8 \%(\mathrm{SD}=7.7)$, however, the allowance of patients with a greater bronchodilator reversibility than $12 \%$ may have contributed to better discrimination between different doses of aclidinium. 
In conclusion, aclidinium is effective at providing sustained bronchodilation over $24 \mathrm{~h}$ without any evidence of treatment-associated tachyphylaxis with a minimum effective dose in patients with moderate to severe chronic COPD of $100 \mu \mathrm{g}$. The safety results confirmed the positive safety profile of aclidinium, particularly in terms of a very low propensity to cause anticholinergic AEs. Based on the efficacy, safety, and tolerability results from this study, aclidinium $200 \mu \mathrm{g}$ once daily was selected for evaluation in phase III studies.

\section{Acknowledgements}

We thank Dr. Mark Hughes from Complete Medical Communications who provided medical writing support funded by Almirall, Barcelona, Spain. 


\section{References}

[1] Rabe KF, Hurd S, Anzueto A, Barnes PJ, Buist SA, Calverley P, et al. Global Strategy for the Diagnosis, Management, and Prevention of Chronic Obstructive Pulmonary Disease: GOLD Executive Summary. Am J Respir Crit Care Med 2007; 176:532-55.

[2] Murray CJ, Lopez AD. Alternative projections of mortality and disability by cause 1990-2020: Global Burden of Disease Study. Lancet 1997;349:1498-504.

[3] Lopez AD, Shibuya K, Rao C, Mathers CD, Hansell AL, Held LS, et al. Chronic obstructive pulmonary disease: current burden and future projections. Eur Respir J 2006;27:397-412.

[4] Engstrom CP, Persson LO, Larsson S, Ryden A, Sullivan M. Functional status and well being in chronic obstructive pulmonary disease with regard to clinical parameters and smoking: a descriptive and comparative study. Thorax 1996;51:825-30.

[5] Domingo-Salvany A, Lamarca R, Ferrer M, Garcia-Aymerich J, Alonso J, Felez M, et al. Health-related quality of life and mortality in male patients with chronic obstructive pulmonary disease. Am J Respir Crit Care Med 2002;166:680-5.

[6] Gavalda A, Miralpeix M, Ramos I, Vilella D, Sentellas S, Alberti J, et al. Aclidinium bromide, a novel muscarinic receptor combining long residence at M3 receptors and rapid plasma clearance. Eur Respir J 2007;30 (Suppl 51):209S-10S.

[7] Schelfhout VJ, Joos GF, Garcia Gil E, Montejo EM.

Bronchodilator/bronchoprotective effects of aclidinium bromide, a novel longacting anticholinergic: a Phase I study. Eur Respir J 2007;30 (Suppl 51):356S.

[8] Joos GF, Schelfhout VJ, Kanniess F, Ludwig-Sengpill A, Garcia Gil E, Montejo E.M. Bronchodilator effects of aclidinium bromide, a novel long-acting 
anticholinergic, in COPD patients: a Phase II study. Eur Respir J 2007;30 (Suppl $51): 210 \mathrm{~S}$.

[9] American Thoracic Society. Standards for the diagnosis and care of patients with chronic obstructive pulmonary disease (COPD) and asthma. Am Rev Respir Dis 1995;152:S77-S120.

[10] Greguletz R, Arlt M, Anke S, Goede J, Haaije de Boer A, Frijlink HW. A novel multidose dry powder inhaler for the delivery of various types of inhalation powder. Am J Respir Crit Care Med 2009;179.

[11] Quanjer PH, Tammeling GJ, Cotes JE, Pedersen OF, Peslin R, Yernault JC. Lung volumes and forced ventilatory flows. Report Working Party Standardization of Lung Function Tests, European Community for Steel and Coal. Official Statement of the European Respiratory Society. Eur Respir J Suppl 1993;16:5-40.

[12] Pellegrino R, Viegi G, Brusasco V, Crapo RO, Burgos F, Casaburi R, et al. Interpretative strategies for lung function tests. Eur Respir J 2006;26:948-68.

[13] Miller MR, Hankinson J, Brusasco V, Burgos F, Casaburi R, Coates A, et al. Standardisation of spirometry. Eur Respir J 2005;26:319-38.

[14] Abrams P, Andersson KE, Buccafusco JJ, Chapple C, de Groat WC, Fryer AD, et al. Muscarinic receptors: their distribution and function in body systems, and the implications for treating overactive bladder. Br J Pharmacol 2006;148:56578.

[15] Tashkin DP, Celli B, Decramer M, Liu D, Burkhart D, Cassino C, et al. Bronchodilator responsiveness in patients with COPD. Eur Respir $\mathbf{J}$ 2008;31:742-50. 


\section{Figure legends}

Figure 1. Patient disposition.

Figure 2. Trough $\mathrm{FEV}_{1}$ values on day 29 (intent-to-treat population).

Figure 3. Trough $\mathrm{FEV}_{1}$ values throughout the study (intent-to-treat population).

Figure 4. Change from baseline in $\mathrm{FEV}_{1} 0-6 \mathrm{~h}$ post-administration (intent-to-treat population). A. Day 1. B. Day 29.

\section{Figure footnotes}

Figure 3: Statistically significant increase compared with placebo for aclidinium $200 \mu \mathrm{g}$ at Day $1(P=0.044)$ and Day $29(P=0.006)$; aclidinium $400 \mu \mathrm{g}$ at Day 15 $(P=0.035)$ and Day $29(P=0.018)$; and tiotropium $18 \mu \mathrm{g}$ at all time points $(P \leq 0.005)$

Figure 4: a) Statistically significant increases from baseline versus placebo at all time points for aclidinium $100 \mu \mathrm{g}(P=0.014), 200 \mu \mathrm{g}(P<0.001)$, and $400 \mu \mathrm{g}(P<0.001)$ and tiotropium $18 \mu \mathrm{g}(P=0.02)$. b) Statistically significant increases over placebo at all time points for aclidinium $100 \mu \mathrm{g}, 200 \mu \mathrm{g}$, and $400 \mu \mathrm{g}$, as well as for tiotropium $18 \mu \mathrm{g}(P<0.001$ in all cases except for the aclidinium $100 \mu \mathrm{g}$ dose: $P=0.006)$. 
Table 1 Demographic and baseline characteristics of the intent-to-treat population

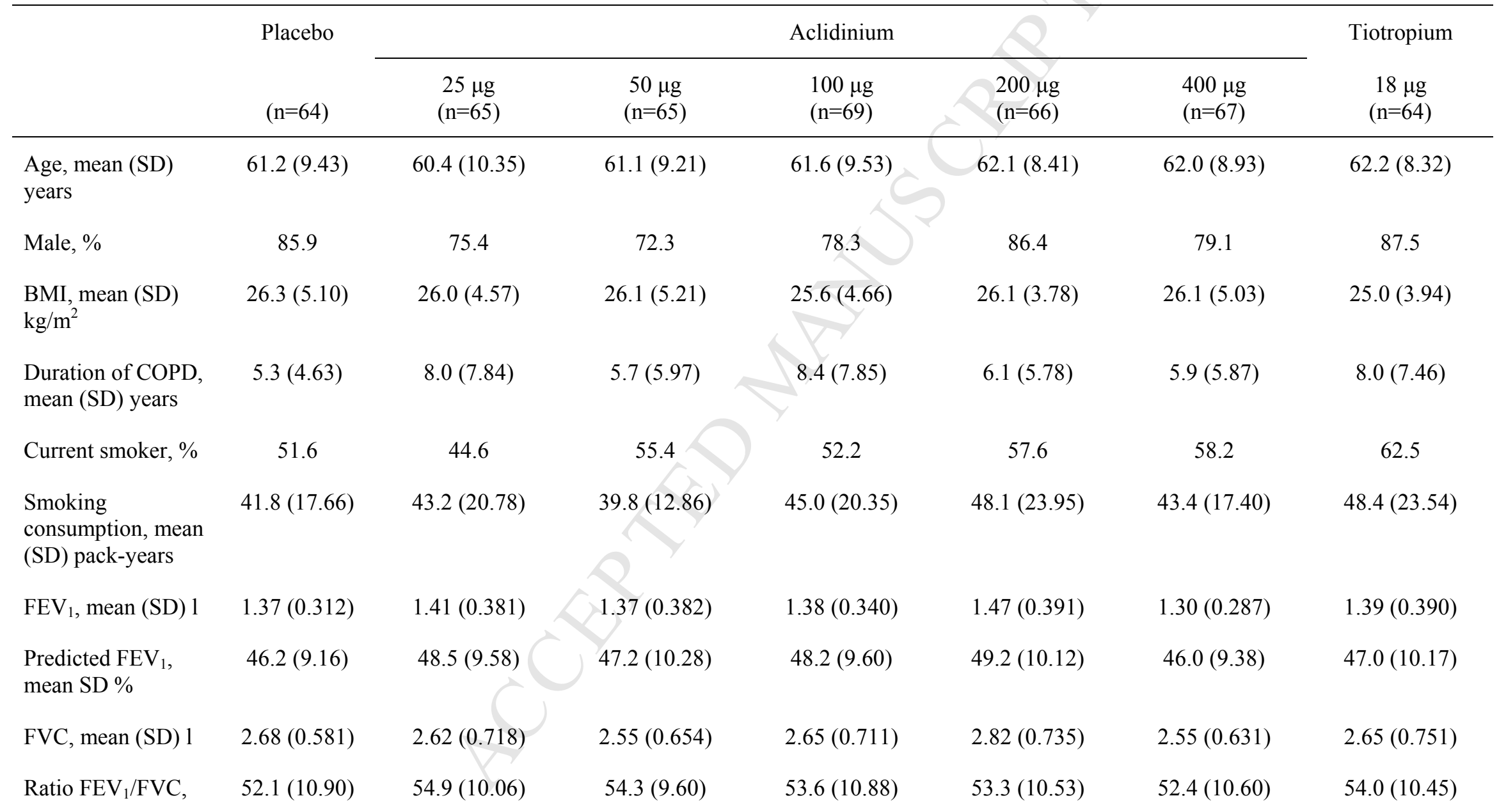


mean (SD) \%

Bronchodilator

$8.5(8.38)$

$7.6(7.60)$

$7.9(7.65)$

$6.8(7.79)$

$9.0(7.24)$

$7.6(7.64)$

$7.1(7.36)$

reversibility, ${ }^{\mathrm{a}}$ mean

(SD) \%

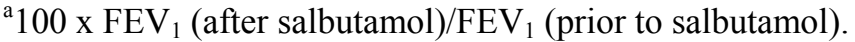


Table 2 Peak $\mathrm{FEV}_{1}$ values (intent-to-treat population)

\begin{tabular}{|c|c|c|c|c|c|c|c|}
\hline & \multirow{2}{*}{$\begin{array}{l}\text { Placebo } \\
(n=64)\end{array}$} & \multicolumn{5}{|c|}{ Aclidinium } & \multirow{2}{*}{$\begin{array}{l}\text { Tiotropium } \\
\qquad \begin{array}{l}18 \mu \mathrm{g} \\
(\mathrm{n}=64)\end{array}\end{array}$} \\
\hline & & $\begin{array}{c}25 \mu g \\
(n=65)\end{array}$ & $\begin{array}{c}50 \mu g \\
(n=65)\end{array}$ & $\begin{array}{l}100 \mu g \\
(n=69)\end{array}$ & $\begin{array}{l}200 \mu g \\
(n=66)\end{array}$ & $\begin{array}{l}400 \mu g \\
(n=67)\end{array}$ & \\
\hline \multicolumn{8}{|c|}{ Least squares mean (SEM) change from baseline versus placebo [95\% confidence interval], 1} \\
\hline Day 1 & NA & $\begin{array}{c}0.031(0.037) \\
{[-0.042,0.103]}\end{array}$ & $\begin{array}{c}0.058(0.037) \\
{[-0.014,0.131]}\end{array}$ & $\begin{array}{c}0.103(0.037) \\
{[0.031,0.174]}\end{array}$ & $\begin{array}{c}0.148(0.037) \\
{[0.076,0.221]}\end{array}$ & $\begin{array}{c}0.123(0.037) \\
{[0.051,0.196]}\end{array}$ & $\begin{array}{c}0.104(0.037) \\
{[0.031,0.177]}\end{array}$ \\
\hline$P$-value & NA & 0.408 & 0.113 & 0.005 & $<0.001$ & $<0.001$ & 0.005 \\
\hline Day 29 & NA & $\begin{array}{c}0.062(0.053) \\
{[-0.043,0.167]}\end{array}$ & $\begin{array}{c}0.104(0.053) \\
{[-0.001,0.209]}\end{array}$ & $\begin{array}{c}0.129(0.053) \\
{[0.025,0.233]}\end{array}$ & $\begin{array}{c}0.202(0.053) \\
{[0.098,0.307]}\end{array}$ & $\begin{array}{c}0.204(0.053) \\
{[0.099,0.308]}\end{array}$ & $\begin{array}{c}0.215(0.053) \\
{[0.048,0.258]}\end{array}$ \\
\hline$P$-value & NA & 0.245 & 0.051 & 0.015 & $<0.001$ & $<0.001$ & $<0.001$ \\
\hline \multicolumn{8}{|c|}{ Median (range) time to peak, hours } \\
\hline Day 1 & $2.0(0.5-6.0)$ & $4.0(0.5-6.0)$ & $4.0(0.5-6.0)$ & $2.0(0.5-6.0)$ & $3.0(0.5-6.0)$ & $3.0(0.5-6.0)$ & $4.0(0.5-6.0)$ \\
\hline Day 29 & $2.0(0.5-6.0)$ & $2.0(0.5-6.0)$ & $2.0(0.5-6.0)$ & $2.0(0.5-6.0)$ & $2.0(0.5-6.0)$ & $3.0(0.5-6.0)$ & $3.0(0.5-6.0)$ \\
\hline
\end{tabular}

Definition of abbreviation: NA: Not applicable. 
Table 3 Adverse events reported by $\geq 2$ patients in any treatment group (safety population)

\begin{tabular}{|c|c|c|c|c|c|c|c|}
\hline & \multicolumn{7}{|c|}{ Number (\%) of patients reporting adverse events } \\
\hline At least one $\mathrm{AE}$ & $8(12.5)$ & $14(21.2)$ & $11(16.9)$ & $19(27.1)$ & $12(17.9)$ & $15(22.4)$ & $17(26.2)$ \\
\hline Dry mouth & $1(1.6)$ & 0 & $3(4.6)$ & $1(1.4)$ & $3(4.5)$ & $1(1.5)$ & $4(6.2)$ \\
\hline $\begin{array}{l}\text { Chronic obstructive } \\
\text { airways disease } \\
\text { exacerbated }\end{array}$ & 0 & $1(1.5)$ & $3(4.6)$ & $1(1.4)$ & $1(1.5)$ & $2(3.0)$ & 0 \\
\hline Cough & $1(1.6)$ & 0 & $3(4.6)$ & 0 & 0 & $1(1.5)$ & $3(4.6)$ \\
\hline Hypertension NOS & $1(1.6)$ & 0 & 0 & $2(2.9)$ & 0 & $1(1.5)$ & 0 \\
\hline $\begin{array}{l}\text { Lower respiratory tract } \\
\text { infection NOS }\end{array}$ & $1(1.6)$ & $2(3.0)$ & 0 & $1(1.4)$ & 0 & 0 & 0 \\
\hline Rhinitis NOS & $1(1.6)$ & 0 & 0 & 0 & $2(3.0)$ & $1(1.5)$ & 0 \\
\hline
\end{tabular}


Page 2

\begin{tabular}{|c|c|c|c|c|c|c|c|}
\hline Fatigue & 0 & $1(1.5)$ & 0 & 0 & 0 & 0 & $2(3.1)$ \\
\hline $\begin{array}{l}\text { Blood glucose } \\
\text { increased }\end{array}$ & 0 & 0 & 0 & 0 & 0 & 0 & $2(3.1)$ \\
\hline Cystitis NOS & 0 & $2(3.0)$ & 0 & 0 & 0 & 0 & 0 \\
\hline $\begin{array}{l}\text { Superventricular } \\
\text { extrasystoles }\end{array}$ & 0 & $2(3.0)$ & 0 & 0 & 0 & 0 & 0 \\
\hline
\end{tabular}

Definition of abbreviation: NOS: Not otherwise specified. 
Excluded $(n=230)$

Non-fulfilment of inclusion/exclusion criteria $(n=178)$

Patient's personal request $(n=21)$

Protocol non-compliance (other than entry criteria $[n=9]$ )

Adverse events $(n=5)$

Other $(n=6)$

Unknown $(n=11)$

\begin{tabular}{|c|c|c|c|c|c|c|}
\hline $\begin{array}{l}\text { Placebo } \\
(n=64)\end{array}$ & $\begin{array}{c}\text { Aclidinium } \\
25 \mu \mathrm{g} \\
(\mathrm{n}=66)\end{array}$ & $\begin{array}{c}\text { Aclidinium } \\
50 \mu \mathrm{g} \\
(\mathrm{n}=65)\end{array}$ & $\begin{array}{c}\text { Aclidinium } \\
100 \mu \mathrm{g} \\
(\mathrm{n}=70)\end{array}$ & $\begin{array}{l}\text { Aclidinium } \\
200 \mu \mathrm{g} \\
(\mathrm{n}=67)\end{array}$ & $\begin{array}{l}\text { Aclidinium } \\
400 \mu \mathrm{g} \\
(\mathrm{n}=67)\end{array}$ & $\begin{array}{c}\text { Tiotropium } \\
18 \mu \mathrm{g} \\
(\mathrm{n}=65)\end{array}$ \\
\hline $\begin{array}{c}\text { Withdrew } \\
\quad(n=3) \\
\text { Adverse events (1) } \\
\text { Lack of efficacy (1) } \\
\text { Personal request (1) }\end{array}$ & \begin{tabular}{|c|} 
Withdrew \\
$(\mathrm{n}=4)$ \\
Did not \\
meet criteria (1) \\
Personal request (2) \\
Other (1)
\end{tabular} & \begin{tabular}{|c|}
$\begin{array}{c}\text { Withdrew } \\
(\mathrm{n}=3)\end{array}$ \\
Adverse events (2) \\
Non-compliance (1)
\end{tabular} & \begin{tabular}{|c|} 
Withdrew \\
$(\mathrm{n}=3)$ \\
Adverse events (1) \\
Personal request (2)
\end{tabular} & \begin{tabular}{|c|} 
Withdrew \\
$(\mathrm{n}=3)$ \\
Adverse events (2) \\
Personal request (1)
\end{tabular} & \begin{tabular}{|c|} 
Withdrew \\
$(n=3)$ \\
Lost to follow-up (1) \\
Personal request (2)
\end{tabular} & $\begin{array}{c}\text { Withdrew } \\
(\mathrm{n}=4) \\
\text { Did not } \\
\text { meet criteria (1) } \\
\text { Lost to follow-up (1) } \\
\text { Adverse events (1) } \\
\text { Personal request (1) }\end{array}$ \\
\hline $\begin{array}{c}\text { Completed } \\
(\mathrm{n}=61)\end{array}$ & $\begin{array}{c}\text { Completed } \\
(n=62)\end{array}$ & $\begin{array}{c}\text { Completed } \\
(\mathrm{n}=62)\end{array}$ & $\begin{array}{c}\text { Completed } \\
(\mathrm{n}=67)\end{array}$ & $\begin{array}{c}\text { Completed } \\
(\mathrm{n}=64)\end{array}$ & $\begin{array}{c}\text { Completed } \\
(\mathrm{n}=64)\end{array}$ & $\begin{array}{c}\text { Completed } \\
(\mathrm{n}=61)\end{array}$ \\
\hline
\end{tabular}


Figure 2

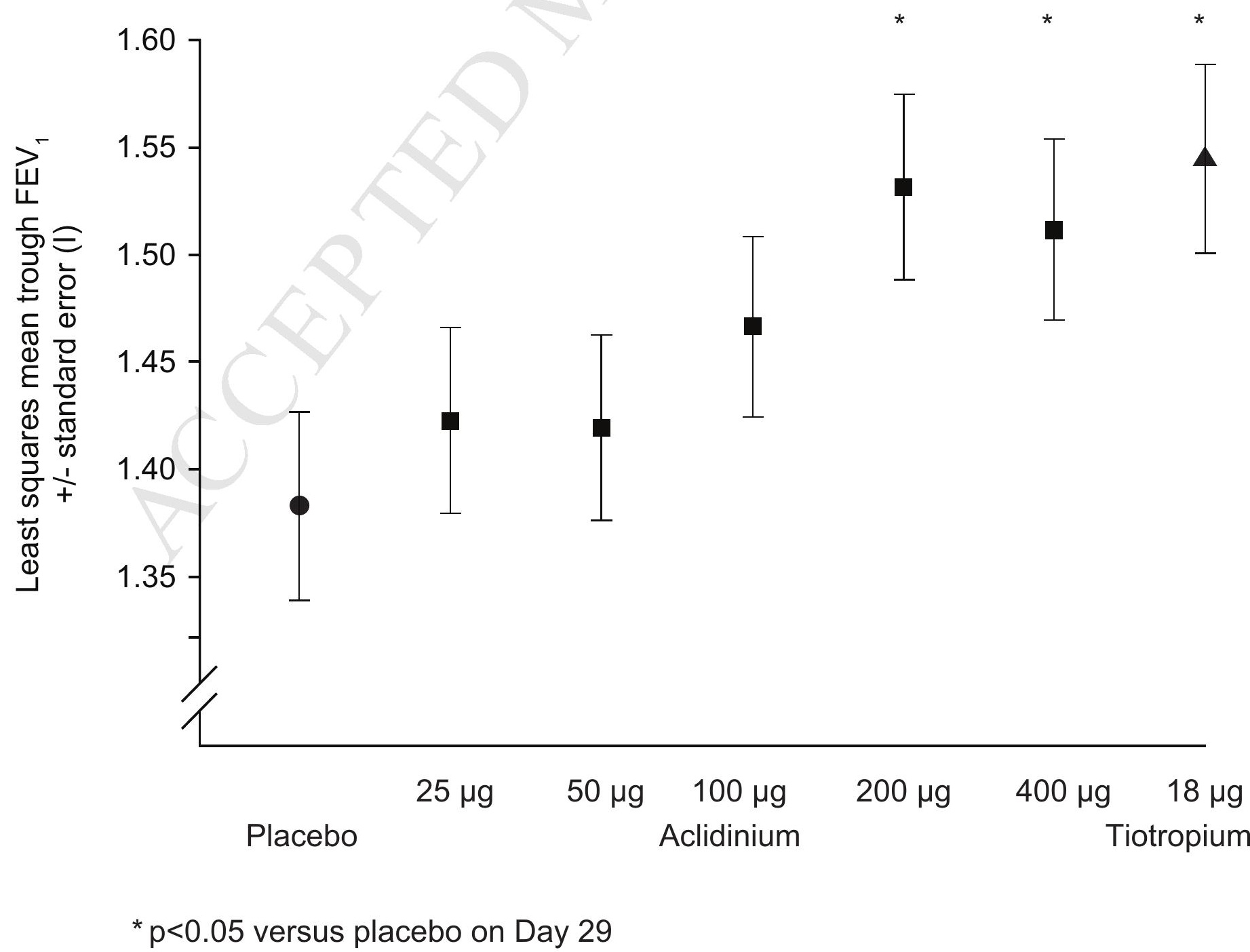




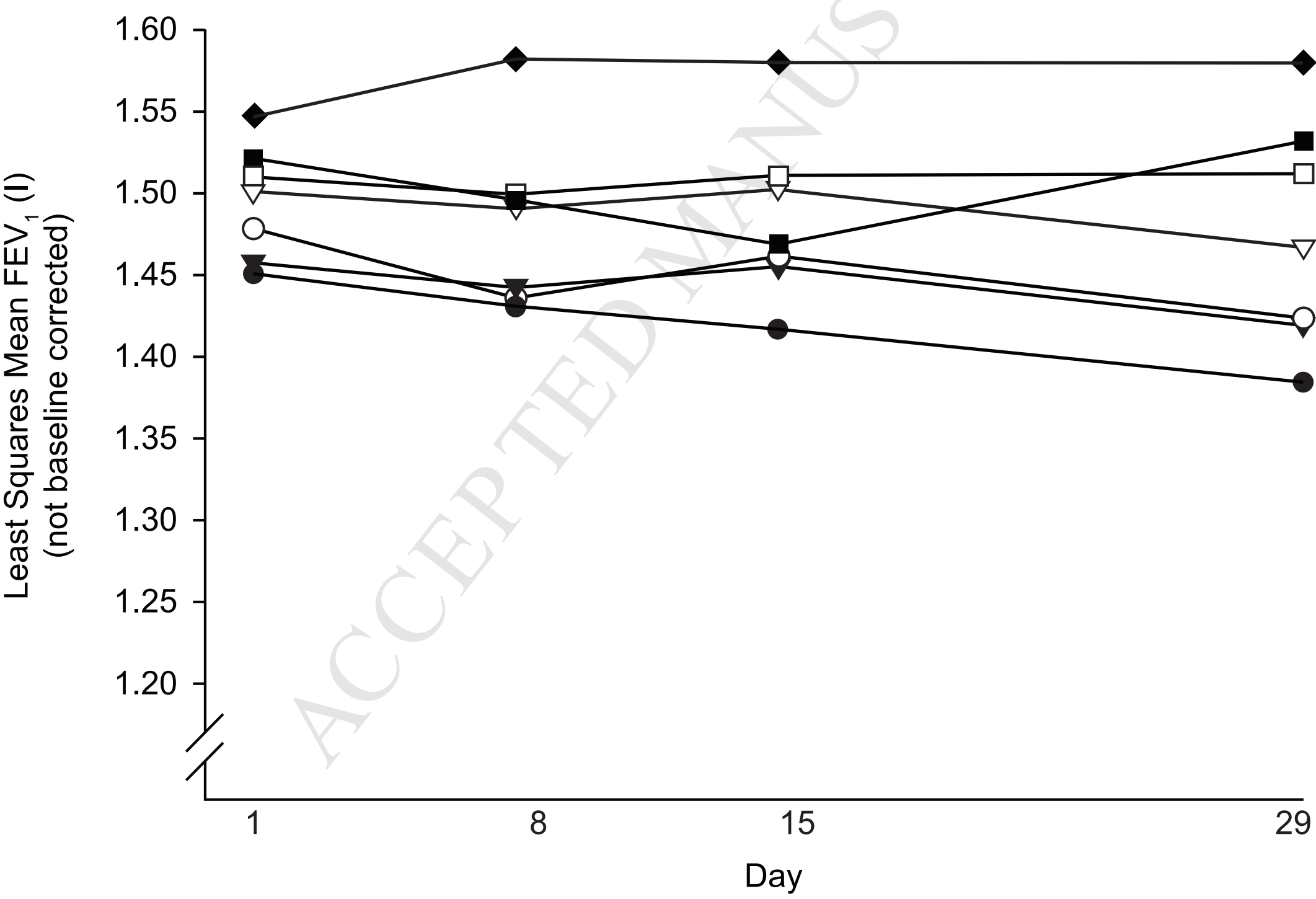

$\longrightarrow$ Placebo

$-\mathrm{O}-$ Aclidinium $25 \mu \mathrm{g} \quad \longrightarrow$ - Aclidinium $200 \mu \mathrm{g}$

$\rightarrow$ Aclidinium $50 \mu \mathrm{g} \quad \longrightarrow$ - Aclidinium $400 \mu \mathrm{g}$

$\neg-$ Aclidinium $100 \mu \mathrm{g} \leadsto$ Tiotropium $18 \mu \mathrm{g}$ 
Figure 4

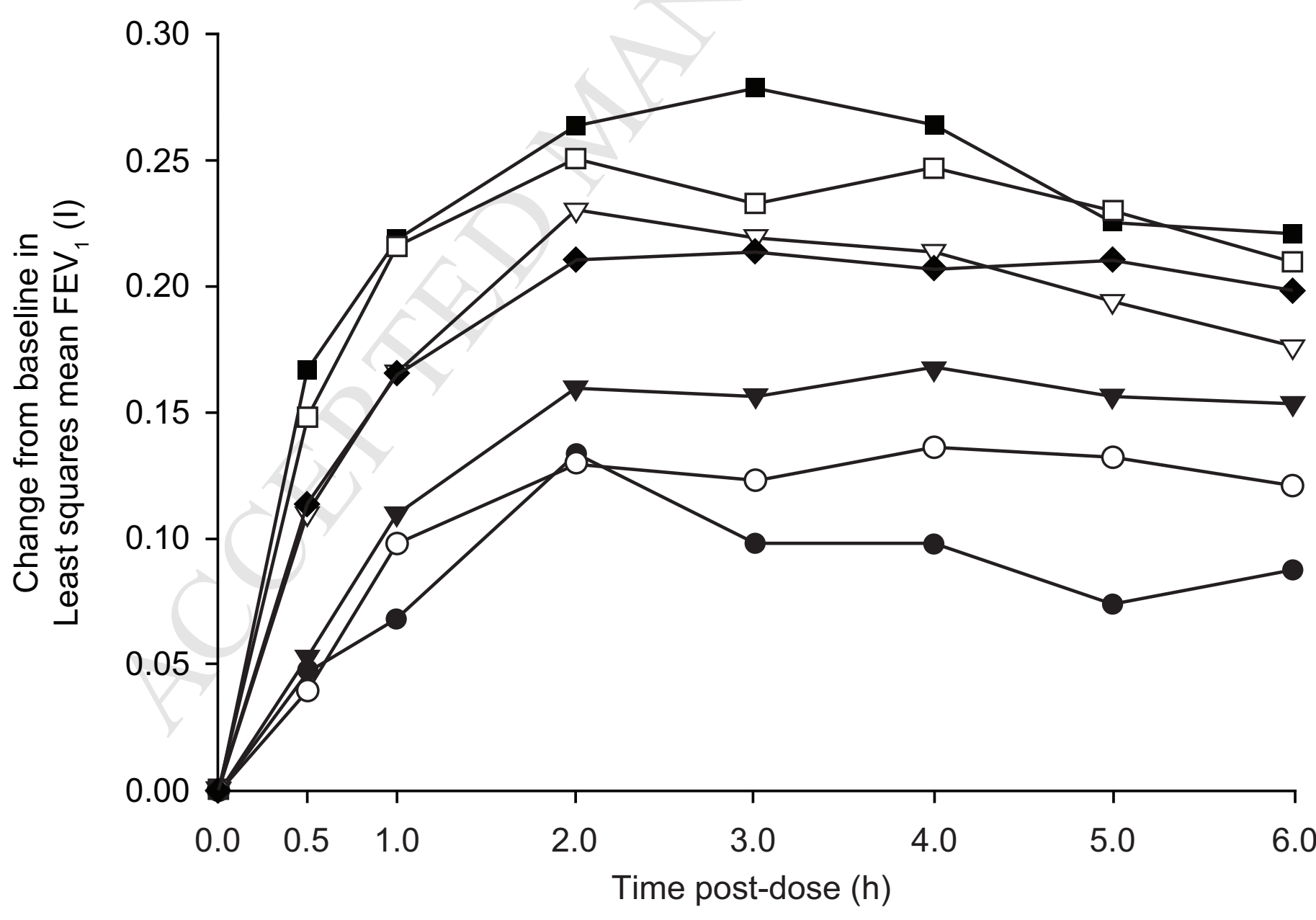

$\longrightarrow$ Placebo

-O- Aclidinium $25 \mu \mathrm{gg} \rightarrow$ Aclidinium $200 \mu \mathrm{g}$

$\rightarrow$ Aclidinium $50 \mu \mathrm{g} \quad-\square-$ Aclidinium $400 \mu \mathrm{g}$

$\neg-$ Aclidinium $100 \mu \mathrm{g} \leadsto$ Tiotropium $18 \mu \mathrm{g}$ 


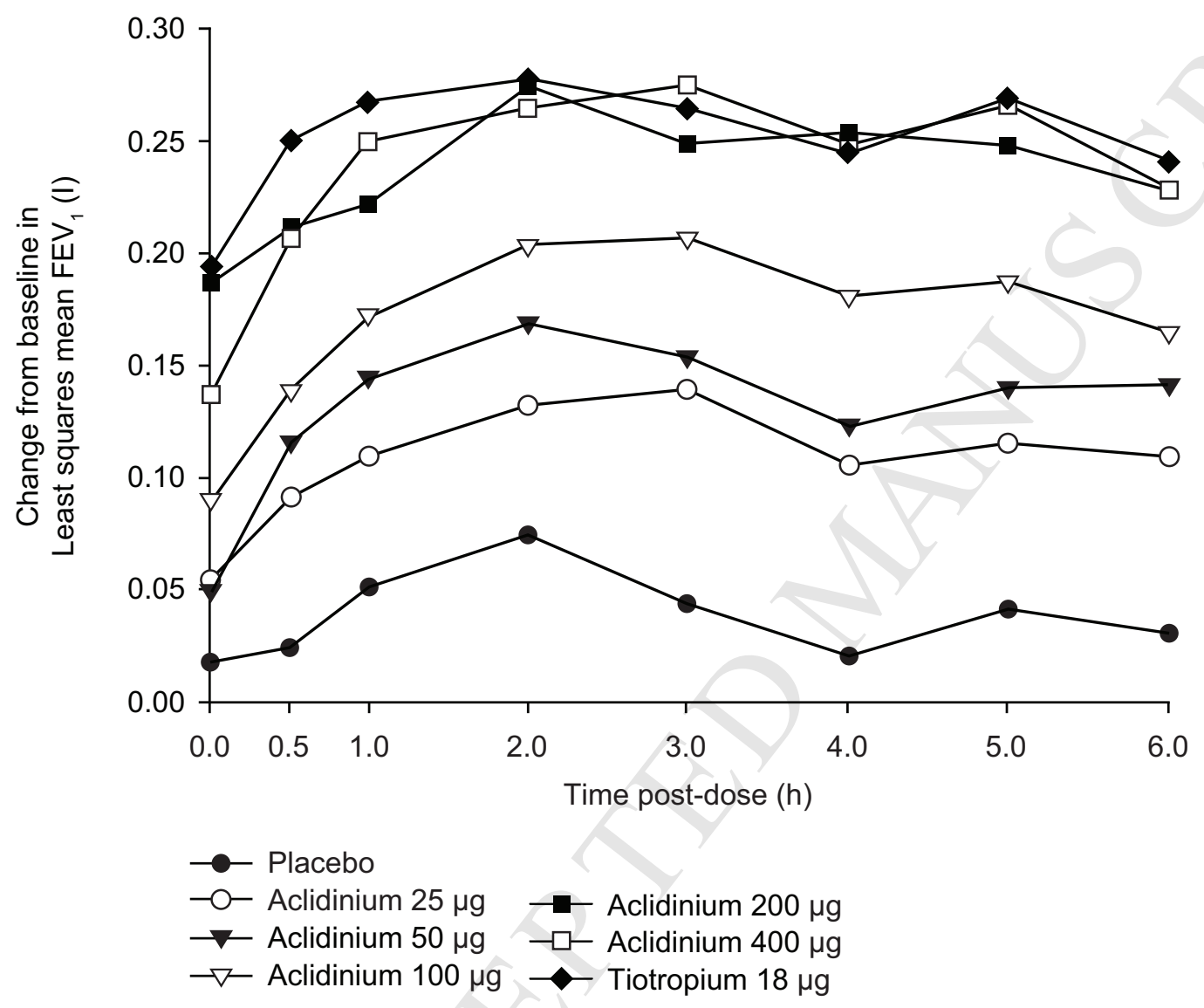

